\title{
KEKUASAAN KEHAKIMAN DALAM PERSPEKTIF NEGARA HUKUM DI INDONESIA
}

\author{
Dachran Busthami \\ Fakultas Hukum, Universitas Muslim Indonesia \\ Jl. Urip Sumoharjo KM 5, Panaikang, Panakkukang, Makassar, Sulawesi Selatan \\ dachran.bustahmi60@gmail.com
}

\begin{abstract}
This paper discusses the legal state as the best choice in organizing a democratic state-based life with a constitution or the Constitution which regulates the relationship between the state and the people, the rights of the citizens and the limitation of the power of the ruler and the guarantee of justice and equality before the law and welfare for community. The research method of this scientific work is legal juridical normative research. Analysis of normative juridical research data is data processing and systematization activities against written legal materials. The results show that only on the concept of law, the judicial power can be independent in carrying out its judicial functions, thus enabling the judicial authorities to exercise fairness in examining, adjudicating and deciding a case based on law and justice.
\end{abstract}

Keywords: State, Power, Justice

Abstrak

Karya ilmiah ini membahas negara hukum sebagai pilihan terbaik dalam menata kehidupan bernegara yang berdasarkan demokrasi dengan suatu konstitusi atau UUD yang mengatur hubungan antar negara dan rakyat, hak-hak asasi warga negara dan pembatasan kekuasaan penguasa serta jaminan keadilan dan persamaan di hadapan hukum serta kesejahtraan bagi masyarakat. Metode penelitian karya ilmiah ini adalah penelitian hukum yuridis normatif. Analisis data penelitian yuridis normatif adalah kegiatan pengolahan data dan sistematisasi terhadap bahan-bahan hukum tertulis. Hasil penelitian menunjukkan bahwa hanya pada konsep bernegara hukum, kekuasaan kehakiman dapat mandiri dalam menjalankan fungsi judisialnya, sehingga memungkinlan pelaksana kekuasaan kehakiman berlaku fair dalam memeriksa, mengadili dan memutus suatu perkara berdasarkan hukum dan keadilan.

Kata Kunci : Negara, Kekuasaan, Kehakiman

\section{A. Pendahuluan}

1. Latar Belakang Permasalahan

Ide ataupun konsep negara hukum pada umumnya dimaksudkan dalam rangka menghindari negara atau pemerintah dari perbuatan sewenang-wenang. Karena bagaimanapun, bahwa suatu pemerintahan yang tidak dikontrol dengan perangkat hukum yang tegas dan konkret akan sangat rentan dengan berbagai bentuk penyimpangan dan penyalahgunaan kekuasaan (Jenpatar Simamora, 2017). Membicarakan hukum tidak lepas dari membicarakan kekuasaan. Hukum ada karena kekuasaan yang sah. Sehinga pada dasarnya ketentuan-ketentuan yang tidak berdasarkan pada kekuasaan yang sah adalah bukan hukum. Hukum pada hakikatnya adalah kekuasaan (Ari Hermawan, 2011).

Hukum mempunyai arti penting bagi kekuasaan karena hukum berperan sebagai sarana legislasi bagi kekuasaan formal bagi lembaga-lembaga negara, unit-unit pemerintahan, pejabat negara dan pemerintahan. Legislasi kekuasaan dilakukan melalui penetapan landasan hukum bagi kekuasaan melalui aturan-aturan hukum positif. Disamping itu pula hukum hukum dapat berpetan pula mengontrol kekuasaan sehingga pelaksanaannya dapat 
dipertanggungjawabkan secara legal dan etis. Sedangkan kekuasaan bermakna penting bagi hukum karena kekuasaan bukan hanya instrumen pembuatan hukum (law making) tapi juga instrumen penegakan hukum (law enforcement) (ArifHidayat, 2013).

Upaya mewujudkan negara hukum sebagaimana yang dicita-citakan dalam Undang-Undang Dasar Negara RI Tahun 1945 (UUD NRI 1945) akan dapat direalisasikan bila seluruh proses penyelenggaraan pemerintahan benar-benar didasarkan pada kaidah-kaidah yang tertuang dalam konstitusi dan UUD (Jenpatar Simmamora, 2014). Secara tekstualkonstitusional dalam penjelasan UUD 1945 (pra amandemen) negara hukum atau rechtstaat menjadi antitesis terhadap negara kekuasaan (machtstaat). Hal ini dipertegas dalam UUD NRI 1945 (amandemen) Pasal 1 ayat (3), "negara Indonesia adalah negara hukum". Dengan demikian pembangunan hukum merupakan faktor yang determinatif terhadap pembangunan negara (Dayanto, 2013).

Problematikanya apakah dengan dicantumkannya secara tekstual dalam suatu konstitusi tentang prinsip negara hukum yang dianut, benar-benar dapat dipastikan bahwa penguasa negara akan menjalankannya sesuai amanah konstitusi atau hanya sekedar rumusan norma formal dalam hukum dasar negara sebagai dokumen sakral yang tersimpan rapi.

Negara hukum adalah negara yang meletakkan norma-norma dasar dan norma turunan dalam bernegara untuk kepentingan hidup bersama segenap elemen dan komponen bangsa secara totalitas. Bukan hanya kepentingan sektarian dan sektoral. Indonesia adalah negara yang sejak semula diproklamirkannya oleh The Founthing Father, dicitakan sebagai negara hukum, sehingga dalam berbagai Konstitusi yang pernah berlaku di Indonesia, semuanya menyatakan secara tegas (formal) Indonesia adalah Negara Hukum (Rechtsstaat) bukan negara kekuasaan (Machtstaat).

\section{Metode Penelitian}

Penelitian ini adalah penelitian hukum yuridis normatif. Analisis data penelitian yuridis normatif adalah kegiatan pengolahan data dan sistematisasi terhadap bahan-bahan hukum tertulis. Data penelitian dianalisis secara kualitatif dan berasarkan kerangka teori yang ada (Jenpatar Simamora, 2017).

\section{B. Hasil dan Pembahasan}

Embrio tentang negara hukum telah dikemukakan oleh Plato, ketika ia mengintroduksi konsep Nomoi, sebagai karya tulis ketiga yang dibuat di usia tuannya. Sementara itu, dalam dua tulisan pertama, Politeia dan Politicos, belum muncul istilah negara hukum. Dalam Nomoi, Plato mengemukakan bahwa penyelenggaraan negara yang baik ialah yang didasarkan pada pengaturan (hukum) yang baik. Gagasan Plato tentang negara hukum semakin tegas ketika didukung oleh Aristoteles (muridnya), yang menuliskannya dalam buku Politica. Menurut Aristoteles, suatu negara yang baik ialah negara yang diperintah dengan konstitusi dan berkedaulatan hukum.

Menurut Philipus M. Hadjon, bahwa kemunculan negara dalam konsep rechtsstaat bertumpu pada sistem hukum kontinental yang disebut "civil law" atau "Modern Roman Law", sedangkan konsep rule of law bertumpu atas sistem hukum yang disebut "common law" (Philipus M Hadjon, 1987). Negara hukum dalam perkembangannya senantiasa dipautkan dengan konstitusi negara, terutama dalam hal pengaturan dan penegasan tentang pembatasan kekuasaan negara untuk menjamin kemerdekaan dan hak-hak dasar warga negara dan perlindungannya. Menurut Sri Soemantri, tidak ada suatu negarapun di dunia ini yang tidak mempunyai konstitusi atau undangundang dasar. Negara dan konstitusi merupakan dua lembaga yang tidak dapat dipisahkan satu dengan yang lain. Dalam batas-batas minimal, negara hukum identik dengan negara yang berkonstitusional atau negara yang menjadikan konstitusi sebagai aturan main kehidupan kenegaraan, pemerintahan, dan kemasyarakatan (Sri Soemantri, 1987).

Sebagai konstitusi Republik Indonesia akan dapat direalisasikan bila seluruh proses penyelenggaraan pemerintah benar-benar didasarkan pada kaidah-kaidah yang tertuang 
dalam konstitusi. Konsep negara hukum itu sendiri ditujukan untuk menghindari negara atau pemerintah berbuat dan bertindak sewenang-wenang (Jenpatar Simmamora, 2013).

Budiono Kusumohamidjojo mengemukakan bahwa pada babak sejarah sekarang, sukar untuk membayangkan negara tidak sebagai negara hukum. Setiap negara yang tidak mau dikucilkan dari pergaulan masyarakat internasional menjelang abad XXI paling sedikit secara formal akan memaklumkan dirinya sebagai negara hukum. Dalam negara hukum, hukum menjadi aturan permainan untuk mencapai cita-cita bersama sebagai kesepakatan politik. Hukum juga menjadi aturan permainan untuk menyelesaikan segala macam perselisihan, termasuk juga perselisihan politik dalam rangka mencapai kesepakatan politik tadi. Dengan demikian, hukum tidak mengabdi kepada kepentingan politik sektarian dan primordial, melainkan kepada cita-cita dalam kerangka kenegaraan (Budiono Kusumohamidjojo, 1999).

Negara hukum menurut Bothling, adalah "de staat, waarin de wilsvriheid van gezagsdragers is beperket door grenzen van recht" (negara, dimana kebebasan kehendak pemegang kekuasaan dibatasi oleh ketentuan hukum). Lebih lanjut disebutkan bahwa dalam rangka merealisasi pembatasan pemegang kekuasaan tersebut, maka diwujudkan dengan cara, Enerzids in een binding van rechter en administratie aan de wet, anderjizds in een begrenzing van de bevoegdheden van wetgever," (di satu sisi keterikatan hakim dan pemerintah terhadap undang-undang, dan di sisi lain pembatasan kewenangan oleh pembuat undang-undang) (Ridwan. HR, 2006).

Konsep Negara Hukum yang dikemukakan oleh Soemantri Martosoewignjo, yaitu pemerintahan dalam melaksanakan tugas dan kewajibannya harus berdasar atas hukum atau peraturan perundang-undangan, adanya jaminan terhadap hak-hak asasi manusia (warga negaranya), adanya pembagian kekuasaan dalam negara, adanya pengawasan dari badan-badan peradilan (Seno Wibowo Gumbira, 2014).
Hamda Zoelva mengatakan bahwa apabila dilihat dari penyelenggaraan lembaga peradilan yang merupakan pelaksanaan kekuasaan dibidang kehakiman dalam sebuah negara hukum, maka negara hukum dimaksud adalah negara yang menempatkan kekuasaan kehakiman sebagai kekuasaan yang merdeka, menghormati hak asasi manusia dan prinsip due process of law (Mukhtari, 2015).

Negara hukum mengandung maksud untuk membatasi kekuasaan daripada penguas a n e gara a g r tidak menyalahgunakan kekuasaannya untuk menindas dan menelantarkan rakyatnya. Negara hukum meletakkan persamaan di hadapan hukum, perlindungan terhadap hakhak fundamental rakyat, dan hukum beserta peradilan yang fair dan adil (Nurul Qamar, 2010).

Artinya sasaran dari negara hukum adalah terciptanya kegiatan kenegaraan, pemerintahan, dan kemasyarakatan yang bertumpu pada keadilan, kedamaian, dan kemanfaatan atau kebermaknaan. Dalam negara hukum, eksistensi hukum dijadikan sebagai instrumen dalam menata kehidupan kenegaraan, pemerintahan, dan kemasyarakatan.

Terhadap penyelenggaraan tugas-tugas pemerintahan dan kenegaraan dalam suatu negara hukum, terdapat aturan-aturan hukum yang tertulis dalam konstitusi atau peraturanperaturan yang terhimpun dalam hukum tata negara. Meskipun demikian, untuk menyelenggarakan persoalan-persoalan yang bersifat teknis, hukum tata negara ini tidak sepenuhnya dapat dilaksanakan dengan efektif. Dengan kata lain, hukum tata negara membutuhkan hukum lain yang lebih bersifat teknis. yakni hukum tersebut adalah hukum administrasi negara.

Menurut Frans Magnes Suseno, bahwa negara hukum yang bertopang pada sistem demokrasi dapat disebut sebagai negara hukum demokratis (democratische rechtsstaat), sebagai perkembangan lebih lanjut dari demokrasi konstitusional. Disebut negara hukum demokratis karena di dalamnya mengakomodasi prinsip-prinsip negara hukum dan prinsip-prinsip demokrasi (Frans Magnes Suseno, 1997).

1. Prinsip Negara Hukum 
Ten Berge, menyebutkan prinsipprinsip negara hukum sebagai berikut : (Berg Ten J.B.JM, 1996)

a. Asas legalitas. Pembatasan kebebasan warga negara (oleh pemerintah) harus ditemukan dasarnya dalam undangundang yang merupakan peraturan umum. Undang-undang secara umum harus memberikan jaminan (terhadap warga negara) dari tindakan (pemerintahan) yang sewenangwenang, kolusi, dan berbagai jenis tindakan yang tidak benar dapat merugikan warganegara/rakyat. Pelaksanaan wewenang oleh organ pemerintahan ditemukan dasarnya pada undang-undang tertulis (undangundang formal).

b. Perlindungan hak-hak asasi

c. Pemerintah terikat pada hukum

d. Monopoli paksaan pemerintah untuk menjamin penegakan hukum. Hukum harus dapat ditegakkan ketika hukum itu dilanggar. Pemerintah harus menjamin bahwa ditengah masyaraka terdapat instrumen yuridis penegakan hukum. Pemerintah dapat memaksa seseorang yang melanggar hukum melalui sistem peradilan negara. memaksakan hukum publik secara prinsip merupakan tugas pemerintah.

e. Pengawasan oleh hakim yang merdeka. Superioritas hukum tidak dapat ditampilkan jika aturan-aturan hukum hanya dilaksanakan organ pemerintahan. Oleh karena itu, dalam setiap negara hukum diperlukan pengawasan oleh hakim peradilan yang merdeka.

Lain dari yang dikemukakan Ten Berge, adalah dari Van Wijk, merumuskan prinsipprinsip negara hukum (rechtsstaat), sebagai berikut:(Jenpatar Simmamora, 2013)

a. Pemerintahan berdasarkan undangundang.

Pemerintah hanya memiliki kewenangan yang secara tegas diberikan oleh UUD atau UU lainnya.

b. Hak-hak Asasi

Terdapat hak-hak manusia yang sangat fundamental yang harus dihormati oleh pemerintah.

c. Pembagian kekuasaan

Kewenangan pemerintah tidak boleh dipusatkan pada suatu lembaga, tetapi harus dibagi-bagi pada organ-organ yang berbeda agar saling mengawasi yang dimaksudkan untuk menjaga keseimbangan.

d. Pengawasan lembaga kehakiman.

Pelaksanaan kekuasaan pemerintahan harus dapat dinilai aspek hukumnya oleh hakim yang merdeka.

Barda Nawawi Arif menyamakan kekuasaan kehakiman sebagai kekuasaan "mengadilil" semata, UUD NRI 1945 (amandemen) lebih menekankan/ menonjolkan pengertian kekuasaan kehakiman dalam arti sempit (Pujiyono, 2012). Salah satu lingkup cabang kekuasaan kenegaraan baik ditinjau dari perspektif teoritis maupun dari perspektif praktik penyelenggaraan negara, adalah kekuasaan kehakiman. Kekuasaan kehakiman menurut sistem ketatanegaraan Indonesia adalah kekuasaan yang merdeka yang dilakukan oleh sebuah Mahkamah Agung dan badan peradilan yang berada di bawahnya, dan oleh sebuah Mahkamah Konstitusi, untuk menyelenggarakan peradilan guna menegakkan hukum dan keadilan (Elisabeth N.B, 2010).

Salah satu prinsip negara hukum adalah adanya jaminan penyelenggaraan kekuasaan kehakiman yang merdeka guna menegakkan hukum dan keadilan. Hal ini ditegaskan dalam Pasal 24 ayat (1) UUD 1945, bahwa kekuasaan kehakiman merupakan kekuasaan yang merdeka untuk menyelenggarakan peradilan guna menegakkan hukum dan keadilan.

Kekuasaan kehakiman yang mandiri dalam arti independen tersebut, ditegaskan pada Pasal 24 ayat (1), ayat (2) dan ayat 3 UUD NRI Tahun 1945, sebagai berikut:

1. Kekuasaan kehakiman merupakan kekuasaan yang merdeka untuk menyelenggarakan peradilan guna menegakkan hukum dan keadilan.

2. Kekuasaan kehakiman dilakukan oleh sebuah Mahkamah Agung dan badan 
peradilan yang berada dibawahnya dalam lingkungan peradilan umum, lingkungan peradilan agama,lingkungan peradilan Militer, lingkungan peradilan tata usaha negara, dan oleh sebuah Mahkamah Konstitusi.

3. Badan-badan lain yang fungsinya berkaitan dengan kekuasaan kehakiman diatur dalam undang-undang.

Bilamana diteliti lebih lanjut tentang kekuasaan kehakiman yang merdeka dalam arti independen, terlepas dari pengaruh kekuasaan lainnya, maka hal itu ditemukan kembali penegasannya dalam UndangUndang Nomor 48 Tahun 2009 tentang Kekuasaan Kehakiman maupun dalam Undang-Undang Nomor 14 Tahun 1985 tentang Mahkamah Agung sebagaimana telah dirobah dengan UU. No. 5 Tahun 2004 tentang Perobahan atas UU. No. 14 Tahun 1985 tentang Mahkamah Agung junto UU. No. 3 Tahun 2009 tentang Perubahan Kedua atas UU. No. 14 Tahun 1985 tentang MahkamahAgung.

Pasal 1 Buitir 1 UU No. 48 Tahun 2009 tentang Kekuasaan Kehakiman menegaskan: Kekuasaan Kehakiman adalah kekuasaan $\mathrm{n}$ e gara y a g m e r d e k u n t u menyelenggarakan peradilan guna menegakkan hukum dan keadilan berdasarkan Pancasila dan Undang-Undang Dasar Negara Republik Indonesia Tahun 1945, demi terselenggaranya Negara hukum Republik Indonesia.

Asas kebebasan kekuasaan kehakiman dalam UU tentang pokok-pokok Kekuasaan Kehakiman meliputi:

1. Bebas dan campur tangan kekuasaan negara dan lainnya.

2. Bebas dari paksaan, direktif atau relomendasi dari pihak ekstra judicial, kecuali dalam hal-hal yang diijinkan oleh UU (I Gusti Ketur Irawan, 2010 ).

Penjelasan Resmi Angka I UU No. 48 Tahun 2009 memuat keterangan yang lebih tegas tentang adanya independensi/ kemerdekaan badan-badan peradilan. Hal tersebut, dijelaskan bahwa:

UUD NRI Tahun 1945 menegaskan Indonesia adalah negara hukum. Sejalan dengan ketentuan tersebut maka salah satu prinsip penting negara hukum adalah adanya jaminan penyelenggaraan kekuasaan kehakiman yang merdeka, bebas dari pengaruh kekuasaan lainnya untuk menyelenggarakan peradilan guna menegakkan hukum dan keadilan.

Seirama dengan penjelasan resmi tersebut, dipertegas pula pada Pasal 3 ayat (1) dan ayat (2) UU. No. 48 Tahun 2009, sebagai berikut:

(1) Dalam menjalankan tugas dan fungsinya, hakim dan hakim konstitusi wajib menjaga kemandirian peradilan.

(2) Segala campur tangan dalam urusan peradilan oleh pihak lain di luar kekuasaan kehakiman dilarang, kecuali dalam hal-hal sebagaimana dimaksud dalam Undang-Undang Dasar Negara Republik Indonesia Tahun 1945.

Penegasan kedudukan kekuasaan kehakiman tersebut di atas, secara struktural dan vertikal berpuncak pada Mahkamah Agung. Hal itu diatur dalam pasal 2 UU No. 14 Tahun 1985 (Perubahannya dengan UU No. 5 Tahun 2004 Junto UU. No. 3 Tahun 2009), bahwa : Mahkamah Agung adalah Pengadilan Negara Tertinggi dari semua lingkungan peradilan, yang dalam melaksanakan tugasnya terlepas dari pengaruh pemerintah dan pengaruh-pengaruh lainnya.

Independensi kekuasaan kehakiman yang dijamin oleh hukum dasar negara dan peraturan perundang-undangan di bawahnya, melekat dilaksanakan oleh hakim-hakim Pengadilan dari badan peradilan di semua lingkungan peradilan dalam melaksanakan fungsi kekuasaan di bidang kehakiman.

Keberadaan kekuasaan kehakiman menunjukan bahwa Indonesia sebagai negara hukum (Eka Kusnita, dkk, 2015). Melalui hakim-hakim dari badan-badan peradilan akan dapat ditegakkan prinsip-prinsip negara hukum, sendi-sendi hukum dan keadilan, meskipun dalam prosesnya kemungkinan akan banyak menemukan benturan-benturan, oleh karena gerakan untuk menegakkan hukum (supremasi hukum) harus berhadapan dengan berbagai aspek kepentingan.

Penyelenggaraan kekuasaan kehakiman diserahkan kepada badan-badan peradilan yang ditetapkan dengan undang-undang 
dengan tugas pokok untuk menerima, memeriksa, mengadili dan menyelesaikan setiap perkara yang diajukan kepadanya.

Oemar Seno Adji mengatakan bahwa hakim bebas dalam memutuskan segala putusannya tanpa ada interpensi atau campur tangan pihak lain. Seorang hakim yang sangat bebas, tidak bersifat memihak dalam menjalankan tugas memutus suatu perkara di peradilan (within the exercise of the judicial function). Kebebasan hakim merupakan kewenangan penting yang melekat pada individu hakim dimana hakim berfungsi sebagai penerapan teks UndangUndang kedalam peristiwa yang kongkrit, tidak sekedar sustantif, tetapi juga memberikan penafsiran yang tepat tentang hukum dalam rangka meluruskan peristiwa hukum yang kongkrit sehingga Hakim dapat bebas memberikan penilaian-penilaian dan penafsiran hukumnya (Ery Satyanegara, 2013).

Sejalan dengan tugas pokok tersebut, maka pengadilan tidak boleh menolak untuk memeriksa dan mengadili suatu perkara yang diajukan oleh yustisiabel dengan dalih bahwa hukumnya tidak ada atau kurang jelas. Hal ini berarti pengadilan wajib untuk memeriksa, mengadili dan memutus suatu perkara yang diajukan oleh pencari keadilan.

Pasal 10 ayat (1) UU. No. 48 Tahun 2009, menegaskan bahwa : Pengadilan dilarang menolak untuk memeriksa, mengadili, dan memutus suatu perkara yang diajukan dengan dalih bahwa hukum tidak ada atau kurang jelas, melainkan wajib untuk memeriksa dan mengadilinya.

Implementasi dari tugas dan fungsi kekuasaan kehakiman yang dijalankan oleh hakim-hakim dari lingkungan peradilan, diharapkan dapat menegakkan hukum dan keadilan secara merdeka, independen, tanpa adanya interfensi, dari lingkungan cabang kekuasaan lainnya dan pengaruh dari unsur lain diluar kepentingan hukum dan keadilan.

Berdasar atas itu pulalah, maka hakim dituntut agar senangtiasa melakukan penggalian, megikuti dinamika sosial, dan memahami nilai-nilai hukum dan rasa keadilan yang hidup dalam masyarakat. Keharusan bagi hakim tersebut, dipertegas pada Pasal 5 UU. No. 48 Tahun 2009, bahwa:

(1) Hakim dan hakim konstitusi wajib menggali, mengikuti, dan memahami nilai-nilai hukum dan rasa keadilan yang hidup dalam masarakat;

(2) Hakim dan hakim konstitusi harus memiliki integritas dan kepribadian yang tidak tercela, jujur, adil, profesional, dan berpengalaman di bidang hukum;

(3) Hakim dan hakim konstitusi wajib menaati Kode Etik dan Pedoman Perilaku hakim.

Tuntutan bagi hakim tersebut, tidak lain adalah merupakan konsekuensi hukum dan profesionalitas hakim dalam menjalankan fungsi kekuasaan kehakiman untuk menegakkan hukum dan keadilan melalui badan-badan peradilan. Adanya independensi hakim dalam menjalankan fungsi kekuasaan kehakiman melalui badan-badan peradilan negara, dimaksudkan agar hakim benar-benar dapat mandiri, bebas dan merdeka dari segala sesuatu campur tangan yang dapat mempengaruhi fungsinya dalam memeriksa, megadili dan memutus suatu perkara yang dihadapkan kepadanya.

Citra lembaga peradilan sangat bergantung pada pundak-pundak hakim, adil tidaknya suatu putusan peradilan turut pula ditentukan oleh palu sidang hakim dibalik jubah hitam kebesarannya. Oleh karena itu, hakim-hakim peradilan dalam menjalankan independesinya dituntut agar semata-mata demi penegakan hukum (Law Eforcment) dalam rangka mewujudkan hukum dan keadilan sebagaimana menjadi cita-cita, ide dan gagasan dari suatu konsep bernegara hukum.

Apabila penghayatan dan keteguhan hakim dalam memaknai indepedensi yang melekat pada pelaksanaan fungsi profesionalitasnya diinsyafi benar, tidak dimaknai keliru dan pula tidak disalah artikan serta juga tidak disalah gunakan, maka di tangan-tangan dan palu sidang hakimlah citra peradilan dapat terangkat menjadi peradilan negara yang agung.

\section{Simpulan}

Berdasarkan uraian pembahasan, maka dapat disimpulkan bahwa pada konsep negara hukum lah kekuasaan kehakiman 
mendapatkan tempat dan kedudukan yang teormat dalam sistem distribusi atau pencabangan kekuasaan. Kekuasaan kehakiman dalam konsep negara hukum, sebagaimana halnya dengan Negara Republik Indonesia, telah meletakkan kerangka dasar sistem kekuasaan kehakiman yang independen, terbebas dari pengaruh unsurunsur kekuasaan lainnya, dalam implementasi fungsi kekuasaan kehakiman. Kekuasaan kehakiman dapat mandiri dalam menjalankan fungsi judisialnya, sehingga memungkinlan pelaksana kekuasaan kehakiman berlaku fair dalam memeriksa, mengadili dan memutus suatu perkara berdasarkan hukum dan keadilan.

\section{DAFTAR PUSTAKA}

Berg Ten J.B.JM, 1996, Besturen deer De Overheid, Deventer

Dayanto, "Rekonstruksi Paradigma Pembangunan Negara Hukum Indonesia Berbasis Pancasila", Jurnal Dinamika Hukum Vol. 13, No.3, September 2013

Djanggih, Hardianto dan Kamri Ahmad, "The Effentiviness of Indonesian National Police of Investigation Function in Banggai Regency Police (Investigation Case Year 2008-2016", Jurnal Dinamika Hukum, Vol. 17, No. 2, 2017

Eka Kusnita, dkk, "Pembatasan Upaya Hukum Kasasi Dalam Sengketa Tata Usaha Negara", Jurnal Ilmu Hukum, Vol.3, No.2, Mei 2015

Elisabeth N.B, Sistem Peradilan Satu Atap dan Perwujudan Negara Hukum menurut UU No. 4 Tahun 2004, Jurnal Mimbar Hukum, Vol.22, No.1, Februari 2010, Yogyakarta: Fakultas Hukum, Universitas Gadjah Mada

Ery Satyanegara, "Kebabasan Hakim Memutus Perkara Dalam Konteks Pancasila (Dintinjau Dari Keadilan Substantif)", Jurnal Hukum dan Pembangunan, Vol.44, No.4,Oktober 2013

Gumbira, Seno Wibowo, "Problematika Peninjauan Kembali Dalam Sistem Peradilan PidanaPasca Putusan Mahkamah Konstitusi Dalam Pasca
SEMA RO No. 7 Tahun 2014, (Suatu Analisa Yuridis dan Asas-Asas Dalam Hukum Peradilan Pidana)", Jurnal Hukum dan Pembangunan, Vol.46, No.1, Januari 2016

Hadjon, Philipus M, 1987, Perlindungan Hukum Bagi Rakyat DI Indonesia, Bina Ilmu, Surabaya

Hermawan, Ari, "Hukum dan Kekuasaan Dalam Hubungannya Dengan Industrial, Jurnal" Mimbar Hukum, (Edisi Khusus) November 2011

Hidayat, Arif, "Dialektika Fungsional Antara Hukum dan Otoritas Kekuasaan Negara", Jurnal Masalah-Masalah Hukum, Vol.42, No.2, Oktober 2013

HR, Ridwan. HR, 2006, Hukum Administrasi Negara, Raja Grafindo, Jakarta

I Gusti Ketur Irawan, "Penerobosan Terhadap Batas-Batas Kebebasan Kekuasaan kehakiman", Jurnal Masalah-Masalah Hukum, Vol.39, No.4. Desember 2010

Kusumohamidjojo, Budiono, 1999, Ketertiban yang Adil, Problematika Filsafat Hukum, Grasindo, Jakarta

Mukhtari, dkk, "Pengawasan Tugas Hakim Pengadilan Negeri Oleh Hakim Pengawas Pengadilan Tinggi (Suatu Penelitian di Wilayah Hukum Pengadilan Tinggi Aceh)", Jurnal Ilmu Hukum, Vol.3, No.1, Februari 2015

Pujiyono, "Rekonstruksi Peradilan Pidana Indonesia Dalam Perspektif Kemandirian Kekuasaan Kehakiman", Jurnal Masalah-Masalah Hukum, Vol.41, No.1, Januari 2012

Qamar, Nurul, 2010, Negara Hukum atau Negara Undang-Undang, Makassar, Pustaka Refleksi

Simamora, Jenpatar, "Tafsir Negara Hukum Dalam Perspekyif Undang-Undang Dasar Negara Republik Indonesia Tahun 1945", Jurnal Dinamika Hukum, Vol.14, No.3, September 2014

Simamora, Jenpatar, "Tafsir Negara Hukum dalam Perspektif Undang-Undang Dasar Negara Republik Indonesia Tahun 1945", Jurnal Dinamika Hukum, Vol., 14, No.3, September 2014

Soematri, Sri, 1987, Prosedur dan Sistem Perubahan Konstitusi, Alumni, Bandung 